\title{
Czy Europa potrzebuje zmiany doktryny ekonomicznej?
}

$\mathrm{W}$

OBLICZU PRZEMIAN politycznych i społeczno-ekonomicznych Europy XXI wieku ze wszech miar zasadna wydaje się zmiana doktryny ekonomicznej. Neoliberalizm, określający obecne stosunki społeczno-polityczne, przestał się sprawdzać jako siła determinująca rozwój gospodarczy ${ }^{1}$. W aspekcie społecznym doprowadził do degrengolady wartości, które legły u podstaw demokracji obywatelskiej. Z kolei w sferze politycznej przyniósł deformację kultury politycznej i ról graczy politycznych. W rezultacie tego doprowadził do postawienia na piedestale partykularnych interesów określonych grup społecznych przy jednoczesnej marginalizacji interesów społeczeństwa ${ }^{2}$. Stąd też nasuwa się pytanie: w jakim kierunku zmierza Europa w zakresie wyboru doktryny ekonomicznej XXI wieku?

Jak wynika z obserwacji europejskiego systemu politycznego najtrudniej jest wyciągnąć wnioski i czerpać naukę z historii społeczności międzynarodowej. Dlatego też celem niniejszego artykułu jest próba zaprezentowania koncepcji społecznej gospodarki rynkowej, która na płaszczyźnie krajowej została w pełni urzeczywistniona w Republice Federalnej Niemiec po 1948 r., a na płaszczyźnie międzynarodowej w powołanej w 1957 r. w Rzymie Europejskiej Wspólnocie Gospodarczej, która legła u podstaw Unii Europejskiej.

Wybór Republiki Federalnej Niemiec nie jest przypadkowy, ponieważ nie tylko bliskość sąsiedzka czy wielostronna współpraca gospodarcza z państwami starego lądu, ale także bycie „rzecznikiem Unii Europejskiej, która jako aktor przemawia jednym głosem na arenie międzynarodowej”3 nakazuje bliżej przyjrzeć się prężnie działającej eko-

\footnotetext{
${ }^{1}$ Por. J. F. Stiglitz, Globalizacja, Warszawa 2005, s. 164.

${ }^{2}$ A. Chodubski, Tradycje $w$ wspótczesne wyzwania samorządowe $w$ Polsce, „Studia z badań nad samorządem" 2008, nr 21, s. 10.

${ }_{3}^{3}$ M. M. Kosman, Europa schyłkowe mocarstwo czy pionier nowego porządku światowego, [w:] Unia Europejska w 2008 roku, red. M. Musiał-Karg, T. Wallas, Poznań 2009, s. 11.
} 
nomice tego kraju. Natomiast wybór Wspólnot Europejskich przyjmuje symboliczny wyraz w konfrontacji z neoliberalnym Zachodem ${ }^{4}$.

W celu przeprowadzenia zmiany doktryny ekonomicznej, na scenach politycznych krajów europejskich, potrzebna jest siła polityczna, która tak jak chadecja w powojennych Niemczech potrafiłaby przyjąć ideologię łączącą inne ugrupowania polityczne, a niepodkreślającą wzajemnych antagonizmów. Z jednej strony zmiany w krajach członkowskich, powstające w wyniku ich oddolnych działań, mogłyby stanowić impuls do podjęcia rewizji doktryny ekonomicznej ponadnarodowych struktur wzajemnej współpracy. Z drugiej strony przyjęcie rozwiązań z poziomu narodowego na poziom europejski zaowocowałaby sprzężeniem zwrotnym, w efekcie którego doszłoby do transferu przyjętego systemu wartości z powrotem na poziom narodowy5. W związku z tym państwa starego kontynentu muszą stawić czoło dwojakim problemom: po pierwsze, brakowi alternatyw między którymi możnaby dokonać wyboru doktryny ekonomicznej, po drugie wyznaczeniu organizacji, instytucji czy nawet partii politycznej, które byłyby gotowe do wprowadzenia nowej wizji ładu społeczno-ekonomicznego do życia politycznego.

Próba znalezienia owej pośredniej drogi pomiędzy klasycznym liberalizmem a kolektywistycznym socjalizmem doprowadziła do wyboru koncepcji społecznej gospodarki rynkowej. Koncepcja ta jest na tyle uniwersalna, iż nie tylko sprawdziła się w niemieckiej gospodarce przeżywającej po drugiej wojnie światowej głęboki kryzys, ale także okazała się właściwą drogą w postępującym procesie integracji europejskiej podkreślając pierwszeństwo interesu wspólnoty nad interesem poszczególnych państw europejskich.

W warunkach ujawniających się procesów unifikacyjnych życia kulturowego charakterystyczne są tendencje decentralizacyjne „odmasawiające życie polityczne i społeczno-gospodarcze. $\mathrm{W}$ ich realizacji wyznacza się ważne miejsce dla samorządu"6. Stąd też, wzorem Niemiec Zachodnich, ogromną rolę w przejściu od neoliberalizmu do koncepcji społecznej gospodarki rynkowej powinny odegrać jednostki samorządu terytorialnego jak i specjalnego.

${ }^{4}$ R. Riedel, Europeizacja - koncepcja, agendy, badania, [w:] Europeizacja - mechanizmy, wymiary, efekty, red. W. A. Pacześniak, R. Riedel, Toruń 2010, s. 21.

${ }^{5}$ J. Ruszkowski, Wstęp do studiów europejskich, Warszawa 2007, s. 48.

${ }^{6}$ A. Chodubski, Tradycje $w$ wspótczesne wyzwania samorządowe $w$ Polsce, „Studia z badań nad samorządem” 2008, nr 21, s. 7. Por. E. Polak, Przemiany cywilizacyjne w sferze kultury materialnej, Gdańsk 1996. 
Przełomowe zdarzenia zawsze przynoszą spory ideologiczne. W obliczu kryzysu zastane systemy: polityczny, społeczny i gospodarczy tracą moc oddziaływania. Państwo uzyskuje czystą kartę, która następnie zostanie zapisana zgodnie ze specyfiką zmieniających się czasów ${ }^{7}$. Zazwyczaj potrzeba rewizji doktryny politycznej podporządkowuje zmianę doktryny ekonomicznej. W Niemczech Zachodnich po drugiej wojnie światowej było odwrotnie - zmiana doktryny ekonomicznej wymusiła zmianę doktryny politycznej. Podobnie rzecz ma się obecnie. Jeżeli otoczeniem systemu politycznego jest system społeczny, to relacje, jakie zachodzą w społeczeństwie wpływają na system ekonomiczny. System polityczny jest uwarunkowany tymi dwoma układami ${ }^{8}$.

Kryzys finansowy pierwszej dekady XXI wieku jest punktem zwrotnym w rozważaniach nad koncepcją nowej doktryny ekonomicznej. Stanowi on wezwanie państw europejskich do przewartościowania dotychczasowej neoliberalnej polityki. W obliczu kryzysu dochodzi do zmiany wpływów na rynku. W efekcie powstają monopole nie tylko w sferze przemysłu i usług ale przede wszystkim w dziedzinie technologii, czego rezultatem są wzajemne konflikty i ścieranie się wzajemnych interesów grup społecznych ${ }^{9}$. Stąd też powstaje przestrzeń na ingerencję państwa w sferę gospodarczą w celu przywrócenia ładu gospodarczego.

Przemiany społeczno-polityczne, jakie wywarły znaczący wpływ na kształtowanie się nowej doktryny ekonomicznej w powojennych Niemczech nie sposób w tym artykule szczegółowo omówić, ale krótki szkic jest niezbędny jako tło do dalszej analizy. Jak wiadomo w wyniku przegranej wojny i bezwarunkowej kapitulacji Niemiec hitlerowskich, obszar III Rzeszy znalazł się pod okupacją mocarstw zwycięskiej koalicji antyhitlerowskiej: Stanów Zjednoczonych, Wielkiej Brytanii i Związku Radzieckiego. Odpowiednio powstały strefy okupacyjne: amerykańska, angielska, radziecka; powstała również strefa francuska. Terytorium owych stref zarządzane było przez władze wojsko-

7 Por. U. Zgóra-Jonszta, Ordoliberalizm a społeczna gospodarka rynkowa Niemiec. Możliwości jej realizacji w Polsce, Katowice 1999, s. 17.

${ }^{8} \mathrm{O}$ końca lat 40. XX wieku obserwuje się kontekstualizm polityki. W skutek tego nie da się oddzielić systemu politycznego od systemu społecznego. Dlatego też przyczynowe powiązania przebiegają miedzy społeczeństwem a systemem politycznym w kierunku od społeczeństwa do systemu. Por. J. G. March, J. P.Olsen, Instytucje. Organizacyjne podstawy polityki, Warszawa 2005, s. 12.

${ }_{9}$ W. Thompson, Systematic Transition. Past, Present and Future, New York 2009, S. 55 . 
we wymienionych mocarstw. Równocześnie pod nadzorem okupacyjnych władz wojskowych rozpoczął się proces demilitaryzacji, denazyfikacji, dekartelizacji i demokratyzacji obszaru byłej Rzeszy Niemieckiej, a wraz z tym postępował proces tworzenia podstaw politycznych i ekonomicznych nowego niemieckiego państwa prawa. Rychło jednak ujawniły się głębokie różnice wśród sojuszników co do ustroju politycznego i gospodarczego przyszłego państwa niemieckiego. Różnice te były tak głębokie, że ostatecznie na obszarze byłej III Rzeszy Niemieckiej powstały w 1949 r. dwa odrębne państwa, mianowicie: Republika Federalna Niemiec, obejmująca strefy okupacyjne Stanów Zjednoczonych, Wielkiej Brytanii oraz Francji oraz na obszarze strefy radzieckiej - Niemiecka Republika Demokratyczna ${ }^{10}$.

Nowopowstałe państwa niemieckie różniły się diametralnie pod względem ustroju politycznego i gospodarczego. Republika Federalna Niemiec, w porównaniu do autorytarnej Niemieckiej Republiki Demokratycznej, w sferze gospodarczej postulowała powrót do leseferyzmu, z wiarą w siłę sprawczą jednostki do podejmowania wyzwań stawianych przez wolny rynek. Ta druga natomiast zakładała, zgodnie z doktryną realnego socjalizmu, kolektywizm wraz z wykonywaniem przez państwo funkcji opiekuńczej wobec jednostek.

Powojenne Niemcy nie były gotowe do przyjęcia ani liberalnej koncepcji gospodarki wolnorynkowej ani gospodarki centralnie planowanej. Przestrzeń powstała na styku tych dwóch rozwiązań zrodziła potrzebę przyjęcia koncepcji, która odpowiadała warunkom w jakich znalazły się Niemcy po drugiej wojnie światowej.

Wspomniana „trzecia droga” polegała na znalezieniu „złotego środka" pomiędzy kolektywizmem a liberalizmem. Stąd też, aby przeciwdziałać narastającej fali kryzysu w społeczeństwie niemieckim, należało przeprowadzić głębokie reformy. Rynek mimo, iż był niedoskonały i wymagał korekt ze strony państwa, nie dał się jednak zastąpić. Dlatego pojawiła się koncepcja odrodzenia rynku w duchu doktryny zwanej ordoliberalizem ${ }^{11}$. Ten nurt ekonomii był właśnie „złotym środkiem” pomiędzy socjalistycznym kolektywizmem a klasycznym liberalizmem. W nowopowstałej Republice Federalnej Niemiec był filozofią społeczną głównej partii politycznej Unii Chrześcijańsko-Demo-

${ }^{10}$ Por. S. Cyganek, Izby przemystowo - handlowe $w$ Polsce i w Niemczech, Poznań 2004, s. $50-59$.

${ }_{11}$ Do przedstawicieli ordoliberalizmu zalicza się: Alexandra Rüstowa (18851963), Wilhelma Röpke (1899-1966), Waltera Euckena (1891-1950), Ludwiga Erharda (1897-1977) Franza Böhma (1895-1977) i Alfreda Müllera-Armacka (1901-1978). 
kratycznej. Nawiązywał do rodzimej filozofii społecznej XVIII i XIX wiecznej (Fichte, Hegel, Schelling i inni) i opartej na tej filozofii niemieckiej doktrynie ekonomicznej tzw. historyzmu ${ }^{12}$. Na porządek w sensie ordo składają się trzy zgodne ze sobą płaszczyzny: struktura społeczeństwa wraz z odpowiadającym jej systemem wartość, władza państwowa i prawo. Ordoliberalizm głosił stabilny i zrównoważony ład społeczny oparty na harmonii interesów wszystkich grup społecznych. Stał na gruncie gospodarki rynkowej opartej na wolności i konkurencji, z odpowiedzialnością socjalną, dopuszczał interwencjonizm państwa w sferze ustawodawstwa socjalnego i polityki społecznej ${ }^{13}$.

Zmęczone i upokorzone społeczeństwo niemieckie potrzebowało wiary w ideę silnego państwa, które integrowałoby całą wspólnotę w imię wyższych wartości nie dopuszczając do preponderancji, czyli przewagi indywidualnych interesów jednostek ${ }^{14}$. Idea aktywnej roli państwa w gospodarce była silnie zakorzeniona w społeczeństwie niemieckim. Jednym z pierwszych przedstawicieli ordoliberalizmu był Wilhelm Röpke, który już w 1923 roku w dziele „Wirtschaftlicher Liberaslismus und Staatsgedanke" 15 wskazał potrzebę zmiany roli państwa w stosunkach gospodarczych, a mianowicie państwo miało wykonywać funkcję arbitra w społeczeństwie w celu łagodzenia sprzecznych interesów pomiędzy małymi grupami społecznymi oraz zwalczaniu monopoli kreowanych przez gospodarkę wolnorynkową ${ }^{16}$.

Ordoliberalizm jako nurt liberalno-chrześcijańska odpowiadała ówczesnemu ugrupowaniu znajdującemu się od 1948 r. u steru władzy, czyli Unii Chrześcijańsko-Demokratycznej. Wymiar metafizyczny, w szczególności przez związek z religijnością oparty na idei ordo, zyskiwał na atrakcyjności w odbiorze społecznym. Ład rynkowy odzyskał moralny sens, ponieważ norma została odczytana z prawa natury. W ten sposób normy i wartości nie były jedynie dziełem człowie-

${ }^{12}$ Por. S. Wykrętowicz, Samorząd jako wyraz demokracji obywatelskiej, [w:] Samorząd $w$ Polsce. Istota, formy, zadania, Poznań 2008, s. 41; E. Taylor, Historia rozwoju ekonomiki, t. I, Poznań 1967, s. 204 i nast.

${ }^{13}$ R. Skarzyński, Państwo i społeczna gospodarka rynkowa. Główne idee polityczne ordoliberalizmu, Warszawa 1994, s. 37.

${ }^{14}$ Por. T. Grabkowski, Rola państwa w gospodarce RFN. Aspekty ogólne i militarno-ekonomiczne, Warszawa 1976, s. 11.

${ }_{15}$ W. Röpke, Wirtschaftlicher Liberalismus und Staatsgedanke, [w:] Gegen die Brandung, Erlenbach 1959, s. 45 i nast.

${ }^{16}$ J. Lewandowski, Neoliberałowie wobec wspótczesności, Gdynia 1991, s. 100; K. Chojnicka, W. Kobuz-Ciembrowicz, Doktryny polityczne XIX i XX wieku, Kraków 2000, s. 126. 
ka, ale elementem wyższego porządku rzeczy. Ordo stało się pewnego rodzaju drogowskazem, w którym kierunku miało podążać odradzające się po wojnie państwo niemieckie. Eucken, uważany za ojca duchownego ordoliberalizmu ${ }^{17}$, traktował „ordo” jako z góry ustanowioną harmonię ${ }^{18}$. Stanowiło to podstawę do tworzenia nowego porządku w aspekcie społecznym, politycznym i prawnym. Ordo to przede wszystkim tworzenie ram prawnych, w granicach których nastąpi rozwój organów, organizacji i instytucji, które zapewnią prawidłowe reprezentowanie interesów całego społeczeństwa. Idea ta stanowi zatem zalążek idei państwa prawa w ładzie powojennym, w jakim znalazły się powojenne Niemcy.

Müller-Armack podkreślał, że ordo ma znaczenie porządku duchowego, wytworzonego poprzez prawa rządzące konkurencją. W rzeczywistości chodziło o to, aby ład zbudowany był w drodze naturalnej, a nie w wyniku rewolucji. Jest to ład będący efektem historii, czyli tego co obiektywne, natomiast wszelkie działania człowieka, w celu wytworzenia odmiennego porządku są nieobiektywne ${ }^{19}$.

Przeprowadzenie reformy gospodarczej w powojennych Niemczech zostało oparte na poglądzie Euckena o systemie ekonomicznym, którego podstawą powinna być wolna konkurencja - najbardziej idealna forma w modelu gospodarki rynkowej ${ }^{20}$. Uważał on, mianowicie, że wolna konkurencja nie może działać swobodnie w ładzie społecznogospodarczym. Na organizmie państwowym spoczywa zatem odpowiedzialność za zahamowanie przenikania skutków synkretyzmu kulturowego oraz ideologicznego. Stąd też musi ono rozpoznawać jasno swoje zadania, czyli bronić kapitalizmu przed kapitalistami, co ozna-

${ }^{17}$ R. Tokarczyk, Wspótczesne doktryny polityczne, Zakamycze 1998, s. 74.

${ }^{18}$ J. Lewandowski, Neoliberałowie wobec..., op. cit., s. 99.

${ }^{19}$ A. Müller-Armack, Wirtschaftspolitik in der sozialen Marktwirtschaft, [w:] Der Christ und soziale Martktwirtschaft, red. P. Boarman, Stutttgart 1955, s. 88.

${ }^{20} \mathrm{~W}$. Eucken odwoływał się do Maxa Webera poszukując rozwiązań liberalnych łączących fakty historyczne i dane statystyczne z nurtami teoretycznymi. Stąd też najprawdopodobniej można było wprowadzić na grunt gospodarki niemieckiej koncepcje wywodzące się z praktyki i doświadczeń empirycznych. Eucken sklasyfikował systemy gospodarcze jako typy idealne. Idealny typ np. gospodarki centralnie sterowanej przeciwstawił aprobowanej czystej gospodarce rynkowej. W ramach czystej gospodarki rynkowej analizował 5 idealnych form rynkowych - monopol, częściowy monopol, oligopol, częściowy oligopol i konkurencję jednostek z uwagi na zakresy potrzebnej wolności ekonomicznej jednostek zajmujących się przedsiębiorczością. Por. J. Lewandowski, Neoliberatowie wobec..., op. cit., s. 99. 
cza tworzenie ram prowadzenia działalności gospodarczej oraz wskazywanie granic konkurencji ${ }^{21}$.

Mimo, iż ordoliberałowie uważali system rynkowy za najbardziej doskonały, wiedzieli jednak, że jest on labilny oraz bardzo kruchy. Zdaniem Euckena: „konkurencja doprowadza do tego, że wolność i ład są wtedy w równowadze, kiedy wolność i odpowiedzialność ściśle łączą się ze sobą uzyskując optymalny zakres"22. Owa zasada optymalizacji wyrażała się w ponoszeniu przez jednostkę odpowiedzialności nie tylko za swój los, ale przede wszystkim za interesy społeczeństwa. Jednostka zatem wykonuje powinności oraz obowiązki, jakie zostały na nią nałożone w związku z członkostwem w szerszej grupie społecznej.

Wolność w tym ujęciu była rozumiana w sensie pozytywnym i negatywnym. Poprzez stworzenie instytucjonalnej infrastruktury dla gospodarki rynkowej zachowano możliwości działania w obszarze przedsiębiorczości. Wolność w sensie negatywnym oznaczała brak ingerencji z zewnątrz. Obszar rynku został ściśle określony prawem, w ramach którego przedsiębiorca mógł swobodnie funkcjonować znając uprzednio konsekwencje, jakie jego działalność mogłaby wywołać. Tymczasem wolność w sensie pozytywnym rozumiano jako udzielenie pomocy osobom, którym nie powiodło się na rynku. Poprzez otrzymaną pomoc, jednostka mogłaby ponownie spróbować swoich sił podejmując aktywne uczestnictwo w grze rynkowej np. jako przedsiębiorca lub też pasywne uczestnictwo polegające na dystrybucji określonego minimum egzystencjalnego.

Ordoliberałowie uważali, że rynek jest systemem demokratycznym, w którym konsumenci wypowiadają się każdego dnia na temat tego, co powinno być produkowane ${ }^{23}$. Stąd też konkurencję uważano za kluczowy mechanizm rynkowy, ponieważ nie dopuszczała ona do osiągnięcia trwałego panowania nad rynkiem przez jakikolwiek podmiot. Gospodarka, której centralnym mechanizmem byłaby konkurencja jest w stanie dostarczać środków umożliwiających prowadzenie właściwej polityki społecznej, stając się podstawą mechanizmu łagodzenia konfliktów klasowych.

${ }^{21}$ Por. W. Eucken, Grundsätze der Wirtschaftspolitik, Tübingen 2004. W. Eucken, Freiheit und wettbewerbliche Ordnung, München 2000.

${ }^{22}$ W. Eucken, Podstawy polityki gospodarczej, Poznań 2005, s. 69 i nast.

${ }^{23}$ Alexander Rüstow nie wahał się np. głosić poglądów o potrzebie powołania policji rynkowej, bezpośrednio nadzorowałaby graczy rynkowych. Miałaby służyć wszystkim, gdyż zmuszałaby uczestników gry rynkowej do dostarczenia tylko tych dóbr i usług, na które zapotrzebowanie zgłaszaliby konsumenci. 
Stąd też państwo przyjęło na siebie odpowiedzialność za umacnianie ładu rynkowego, w ramach którego jest realizowana zasada wolnej konkurencji. Wykonuje ono dwojakiego rodzaju zadania: po pierwsze likwiduje grupy interesu lub ogranicza ich wpływy po drugie kształtuje ład ekonomiczny bez bezpośredniego zajmowania się gospodarką. W ramach instytucjonalno-prawnych granic gospodarki wolnorynkowej ma miejsce gra rynkowa, w której indywidualni uczestnicy są niezdolni do podporządkowania sobie innych osób. Eucken zaznaczał, że przy niekontrolowanej wolnej konkurencji dochodzi zatem do podziału władzy i wpływów, co doprowadzić może do deformacji rynku i powstania monopoli ${ }^{24}$.

Występowanie jednocześnie obu zasad funkcjonowania rynku gwarantowało, według ordoliberałów, spełnianie zadań konkurencji, do których zaliczano: po pierwsze występowanie na rynku równowagi producentów i konsumentów, przy założeniu, że żaden z nich nie może uzyskać bezpośredniego wpływu na cenę, po drugie konkurencja odbywała się zgodnie z regułami obowiązującymi wszystkich uczestników.

System społecznej gospodarki rynkowej powinien funkcjonować w następujący sposób, iż każde nowe pojawienie się podmiotu jako pracodawcy lub pracobiorcy na rynku budziłoby zainteresowanie ośrodków decyzyjnych. Dzięki temu walka konkurencyjna będzie mogła odbywać się przy zrozumieniu tego co ma miejsce wewnątrz systemu politycznego, bez potrzeby rozwiązania konfliktu między stronami $^{25}$. Najważniejszym celem jest zatem zachowanie ładu rynkowego, który będzie osiągnięty przez współdziałanie wzajemnie powiązanych ze sobą elementów.

Dojrzewanie koncepcji społecznej gospodarki rynkowej sformułowanej w ostatecznym brzmieniu przez A. Müller-Armacka w 1946 r. zostało poprzedzone koncepcjami Rüstowa z 1932 r., oraz Röpkego ${ }^{26}$. Ta pierwsza, zwana koncepcją liberalnego interwencjonizmu, uznawała konieczność kontrolowania procesów zachodzących w gospodarce. Zakładała ograniczone oddziaływanie na rynek, w sposób nie poddający go totalnej kontroli ze strony państwa lecz wzmacniając w nim skuteczność pewnych praw, np. poprzez powiększenie ilości podmiotów biorących udział w grze rynkowej.

${ }^{24}$ W. Eucken, Podstawy polityki..., op. cit., s. 69 i nast.

${ }^{25}$ Szerzej: R. A. Dahl, Dilemmas of Pluralist Democracy: Autonomy vs. Control, New Haven: Yale University Press 1982.

${ }^{26}$ R. Skarzyński, Państwo i społeczna gospodarka rynkowa..., op. cit., s. 7. 
Röpke z kolei nawiązując do idei Rüstowa stworzył koncepcję zwaną: „pozytywną polityką gospodarczą” (związana z deproletaryzacją i decentralizacją) ${ }^{27}$, polegającą na wspieraniu rynku. W dziele „Die Gesellschaftskrisis der Gegenwart"28 Röpke zaproponował dwa sposoby oddziaływania na rynek. Pierwszy sposób, zwany „polityką ramową", polegał na rozbudowie instytucji, które stanowiłyby podstawę rozwijania konkurencji na rynku, jako swoistego fundamentu gospodarki rynkowej. Natomiast drugim sposobem była tzw. „polityka rynkowa”, zwana dalej liberalnym interwencjonizmem. U jej podstaw znajdowały się dwie zasady: po pierwsze zasada wdrażania interwencjonizmu dopasowującego, po drugie zasada interwencjonizmu tylko w granicach gospodarki rynkowej. Pierwsza z nich polegała na złagodzeniu niedogodności rynku oraz wspieraniu słabych grup społecznych w celu utrzymania dużej liczby podmiotów na rynku. Jego zdaniem istnieją takie dziedziny: jak rolnictwo, rzemiosło, drobna przedsiębiorczość, które wymagają specjalnej ochrony, ponieważ spełniają one funkcję stabilizującą w społeczeństwie. Druga zasada polityki rynkowej uzasadniała tymczasem wdrażanie interwencjonizmu tylko na podstawie zasad przewidzianych w gospodarce rynkowej niedopuszczając jednocześnie do zwalczania wszelkich innych form ingerencji, ponieważ doprowadziłoby to do rozwoju kolektywizmu.

Pojęcie i istota społecznej gospodarki rynkowej została po raz pierwszy przedstawiona przez Müllera-Armacka w 1946 r. ${ }^{29}$. Koncepcja ta miała charakter całościowy, polegający na tym, że dojdzie do pogodzenia wolnej przedsiębiorczości, zrodzonej na bazie ludzkiej inicjatywy, z zabezpieczeniami socjalnymi. W tym celu przyjęto dwa założenia: po pierwsze - wolny rynek jest instytucją, która umożliwia najbardziej dynamiczną aktywność człowieka, co prowadzi do wzro-

${ }^{27}$ Deproletaryzacja oznacza nadanie w społeczeństwie charakteru powszechności własności prywatnej, przez co jednostki z osób nie posiadających środków produkcji staną się ich właścicielami. Poprzez skorelowanie postulatu deproletaryzacji z katolicką nauką społeczną doszłoby do próby przywrócenia harmonii pomiędzy jednostkami a społeczeństwem rozumianym jako zbiór jednostek. Röpke pisał, że „w dłuższym horyzoncie czasu, problem proletariatu może mieć tylko dwa ostateczne rozwiązania: po pierwsze, wszyscy ulegniemy proletaryzacji czy to w wyniku nagłej rewolucji (jak w Rosji) czy to stopniowo (jak w innych krajach); po drugie, przekształcimy proletariuszy w posiadaczy, dopełniając tego co encyklika papieska Quadrgesimo Anno trafnie określa mianem redemptio proletarium"; por. J. Lewandowski, Neoliberałowie wobec.., op.cit., s. s. 103.

${ }^{28}$ Szerzej: W. Röpke, Die Gesellschaftskrisis der Gegenwart, Bern 1979.

${ }^{29}$ Szerzej: A. Müller-Armack, Wirtschaftslenkung und Marktwirtschaft, Hamburg 1947 . 
stu wydajności jego pracy, po drugie konieczna jest realizacja zabezpieczeń społecznych, aby tym, którzy nie mogliby sprostać wyzwaniom rynkowym zapewnić godne życie.

Ład gospodarki rynkowej to rozwinięta w procesie historycznym forma organizacyjna. Państwo, poprzez specyficzne położenie rynku, dba o to, żeby jednostka zdobyła znaczenie przez swoją wydajność. W ten sposób społeczna gospodarka rynkowa umożliwia postęp i znalezienie przez jednostkę miejsca w społeczeństwie w zależności od własnej przedsiębiorczości. Müller-Armack mawiał, iż: „nie można spoglądać tylko na procesy rynkowe, ale trzeba widzieć organizację państwową, która poprzez opodatkowanie i zabezpieczenia społeczne (w tym ubezpieczenia społeczne, renty, dodatki mieszkaniowe, premie) ma korygować tworzenie dochodów".

Tak rozumiany porządek rynkowy wymaga ingerencji państwa. Po pierwsze, państwo powinno dbać o to, aby zasada wolnej konkurencji była przestrzegana, ponieważ tylko wtedy rynek może spełniać przewidziane dla niego funkcje. Stąd konieczność zwalczania monopoli. Po drugie, państwo powinno stworzyć pewnego rodzaju politykę stymulującą konkurencję, w przeciwnym razie odrodzą się tradycyjne związki i dojdzie do podziału wpływów na rynku. Po trzecie, państwo powinno także dbać o właściwą strukturę gospodarki, dążyć do zagwarantowania możliwie wysokiego poziomu zatrudnienia czy też wspomagania procesów pobudzających koniunkturę. Interwencjonizm ma też obejmować budownictwo, handel zagraniczny, ceny i kredyty.

W aspekcie strukturalnym Müller-Armack postulował podobne założenia jak Röpke. Mianowicie odnosił się do deproletaryzacji, decentralizacji, a następnie odrodzenia małych i średnich przedsiębiorstw. Głosił tezy odnoszące się do rekonstrukcji stosunków panujących w zakładach pracy w celu przywrócenia podmiotowości osobom zatrudnionym. Stanowiło to zalążek idei oparcia działalności przedsiębiorstw i zakładów na szerokim samorządzie pracowniczym, w którym zrzeszony byłby czynnik pracowniczy obok czynnika zarządzającego ${ }^{30}$.

Polityka gospodarcza winna przyjąć za cel zabezpieczenie ludności przed skutkami kryzysu, czemu służyłyby w szczególności inwestycje państwowe, które pobudzałyby koniunkturę gospodarczą. Państwo niemieckie po drugiej wojnie światowej tworząc nowe miejsca pracy np. w budownictwie mieszkaniowym, podjęło próbę rozwinięcia systemu ubezpieczeń społecznych dla pracowników, gwarantując przy

${ }^{30}$ R. Skarzyński, Państwo i spoteczna gospodarka rynkowa..., op. cit., s. 57 i nast. 
tym płace minimalne poprzez odpowiednie umowy określone w ustawach. W aspekcie polityki socjalnej koncepcja społecznej gospodarki rynkowej polegała na przesunięciu części dochodów osiąganych na rynku w sferę socjalną. Przemieszczenie środków finansowych miało na celu uregulowanie wydajności pracy tak, aby nie spadła wartość środków produkcji.

Ideałem społecznej gospodarki rynkowej w zakresie redystrybucji dochodu było czerpanie środków od ludzi bogatych, posiadających wysokie dochody, przekazując je następnie ubogim pod postacią np. udzielanych dodatków rodzinnych, mieszkaniowych i innych. Zasada ogólnego swobodnego kształtowania się cen na rynku stanowiła warunek funkcjonowania wspomnianego systemu redystrybucji w taki sposób, aby rynek mógł funkcjonować bez zakłóceń.

Społeczeństwo w społecznej gospodarce rynkowej powinno cechować się daleko idącą integracją. Nie jest możliwe wyeliminowanie wszystkich konfliktów w społeczeństwie. Stąd też państwo powinno dążyć do upowszechnienia czynników spajających wspólnoty ludzkie w różnych sferach życia gospodarczego. W przytoczonych poglądach Müllera-Armacka można odnaleźć żywą ideę samorządu gospodarczego, która będzie polegała na tworzeniu form zdecentralizowanej administracji publicznej w sferze gospodarki.

W ramach społecznej gospodarki rynkowej oprócz wymagań stawianych członkom społeczeństwa wyodrębniono także zasady indywidualnej działalności jednostek, które opierają się na korzystaniu z możliwie jak największego zakresu wolności. Oczekuje się, że jednostka zaistnieje na rynku, będzie samodzielna i odpowiedzialna za swoje działania. Może zatem być pracownikiem najemnym lub przedsiębiorcą, dzięki temu uzyska odpowiednie dochody. Społeczna gospodarka rynkowa różni się tym od leseferystycznej wizji ekonomii, że człowiek, nie spełniający wymagań stawianych przez rynek, posiada prawo do oczekiwania pomocy, pozwalającej mu na dalszą egzystencję. Jednostka zatem nie będzie pozostawiona samej sobie, lecz w razie potrzeby będzie miała prawo oczekiwać pomocy ze strony państwa.

Ordoliberalna koncepcja społecznej gospodarki rynkowej została urzeczywistniona w Niemczech Zachodnich po drugiej wojnie światowej w polityce ministra gospodarki i wicekanclerza Ludwiga Erharda. Epoka wdrażania społecznej gospodarki rynkowej przypadała w Niemczech na lata 1948-1963 nazywanych okresem adenauerowskim ${ }^{31}$. Na

${ }^{31}$ E. Cziomer, Historia Niemiec współczesnych 1945-2005, Warszawa 2006, s. 108. 
fali jej popularności oparto stosunki ekonomiczne miedzy państwami członkowskimi Europejskiej Wspólnoty Węgla i Stali oraz Europejskiej Wspólnoty Gospodarczej powołanej w 1957 r.

Realizacja koncepcji Müllera-Armacka wymagała pewnego kompromisu politycznego, który stanowił miarę poziomu kultury politycznej społeczeństwa. Interesy grup społecznych czy też państw muszą zatem uwzględnić wymagania stawiane przez system gospodarczy i społeczny, tworząc pewną całość. Stąd też w okresie pierwszego rządu Konrada Adenauera w latach 1949-1953 utworzono koalicję CSU/CDU z FDP, a nie z SPD. Koalicja CSU/CDU z FDP zmierzała w polityce wewnętrznej do wprowadzenia społecznej gospodarki rynkowej oraz do rozwiązania następujących problemów społecznych: bezrobocia, wsparcia budownictwa mieszkaniowego, rolnictwa, integracji uchodźców, osób wypędzonych oraz inwalidów niemieckich w Zachodnich Niemczech ${ }^{32}$. Natomiast w aspekcie tworzenia podstaw Unii Europejskiej podkreślano budowanie podmiotu ponadpaństwowego, który miałby nie tylko uczestniczyć jako podmiot na scenie międzynarodowej, ale także łagodzić sprzeczne interesy poszczególnych państw ${ }^{33}$. Stąd też idea silnego państwa została początkowo urzeczywistniona w Niemczech Zachodnich, a następnie przeniesiona na płaszczyznę międzynarodową - gdzie podmiot predestynujący do organizacji ponadpaństwowej przyjął na siebie odpowiedzialność za łagodzenie konfliktów między państwami oraz umacnianie ładu nie tyle rynkowego, ale przede wszystkim politycznego, w celu wypracowania najbardziej optymalnej drogi rozwoju Europy.

Społeczna gospodarka rynkowa jest udaną próbą wiązania rozwoju gospodarczego z postępem społecznym przy zastosowaniu korygujących instrumentów interwencji państwa ${ }^{34}$, a w aspekcie ponadnarodowym przy funkcjonowaniu europejskich struktur współpracy. W ramach koncepcji państwa prawa mieści się utworzenie jednolitego prawodawstwa także w sferze socjalnej, ponieważ tylko w taki sposób będzie można zagwarantować poszanowanie praw jednostek przez organy władzy państwowej i organizacji ponadnarodowych. Państwo zatem tworząc podstawy dla efektywnego systemu gospodarczego dąży do zapewnienia bezpieczeństwa fizycznego i socjalnego obywateli oraz

${ }^{32}$ Ibidem, s. 110 .

${ }^{33} \mathrm{~K}$. Iszkowski, Po co nam Europa? O rozbieżnych wizjach integracji, Warszawa 2009, s. 9.

34 A. Müller - Armack, Soziale Marktwirtschaft. Handwüterbuch der Sozialwissenschfaten, Stuttgart 1956, s. 90. 
producentów podstawowych dóbr publicznych. Szczególnie istotne jest wskazanie efektywnego społecznie działania instytucji państwowych ${ }^{35}$, mających na celu uwolnienie ludzi od ryzyka wynikającego z określonych okoliczności np.: utraty pracy, konieczności przekwalifikowania się, choroby, nieszczęśliwych wypadków czy starości ${ }^{36}$. Wzmocnieniem działalności państwa w sferze socjalnej są regulacje prawne przyjmowane na szczeblu europejskim.

W zakresie zabezpieczeń społecznych Erhard początkowo dążył, zgodnie z koncepcją Bismarcka i ordoliberałów do likwidacji różnic $\mathrm{w}$ dochodach, opierając się na wprowadzeniu odpowiedniego systemu redystrybucji. W późniejszym czasie poszerzył tę koncepcję zakładając, że zlikwidowanie różnic dochodowych może odbyć się tylko w ramach polityki gospodarczej przez powiązanie wolności gospodarczej z odpowiedzialnością społeczną - czyli odpowiedzialności za siebie i społeczeństwo ${ }^{37}$.

Głównym celem, jaki przyświecał nowemu rozłożeniu obciążeń finansowych na obywateli, było stworzenie równych warunków egzystencji jednostek w społeczeństwie. Naczelna teza Erharda w zakresie polityki społecznej brzmiała: „dobrobyt dla wszystkich i dobrobyt przez konkurencję". W jej ramach wyrażała się ordoliberalna koncepcja powiązania polityki społecznej z tym, co dzieje się na rynku przez zapewnienie prawnej ochrony jednostkom. W wyniku tego nastąpiła zmiana pojęcia niemieckiej polityki społecznej, która od tego czasu ma na celu doprowadzenie do zabezpieczenia socjalnego każdej jednostki, a nie tylko wybranej klasy społecznej ${ }^{38}$.

Erhard realizując koncepcję społecznej gospodarki rynkowej podkreślał nierozerwalny związek z zasadą sprawiedliwości społecznej. Dążył do zapewnienia ekwiwalentności godności jednostek w społe-

35 Por. S, Golinowska, Polityka społeczna $w$ gospodarcze rynkowej, Warszawa 1994, s. 8.

${ }^{36}$ J. Piasny, J. Woś, System zabezpieczenia socjalnego ludności w Republice Federalnej Niemiec, Poznań 1992, s. 8.

${ }_{37}$ T. Kaczmarek, P. Pysz, Ludwik Erhard i spoleczna gospodarka rynkowa, Warszawa 2004, s. 113 - 114.

${ }^{38} \mathrm{~W}$ pierwszej połowie XX wieku polityka społeczna była rozumiana jako polityka zmierzająca do dobrobytu na rzecz danej klasy, która jest zmuszona użytkować swoja siłę roboczą na rzecz innych w najemnym stosunku pracy. Szerzej: M. Szylko-Skoczny, Polityka społeczna RFN, „Polityka Społeczna” 1987, nr 5 - 6, s. 29. Obecnie w definicji polityki społecznej akcentuje się potrzebę objęcia ochroną wszystkich jednostek przed socjalnymi skutkami zagrażającymi prawidłowemu funkcjonowaniu jednostki. Por. H. Lampert, Lehrbuch der Sozialpolitik, Berlin, Heidelberg, New York, Tokyo 1985, s. 89. 
czeństwie, poprzez wyrównanie szans wszystkich grup społecznych. Tą zasadę urzeczywistniono poprzez równomierny podział korzyści osiągniętych w wyniku postępu społecznego ${ }^{39}$. Inną zasadą była zasada bezpieczeństwa socjalnego, której celem było zagwarantowanie odpowiednich warunków życia oraz udzielania pomocy jednostkom, które znalazły się w trudnej sytuacji życiowej m.in. z powodu utraty pracy, choroby.

Powołana w 1951 r. Europejska Wspólnota Węgla i Stali w zakresie polityki społecznej postulowała poprawę standardów życia społeczeństw państw członkowskich. Ten cel realizowała poprzez kontrolę cen produkcji węgla i stali, zabezpieczenie interesów robotników, producentów i użytkowników ${ }^{40}$. Z kolei polityka społeczna w Europejskiej Wspólnocie Gospodarczej został wyrażona już w jednym z celów jej powołania, mianowicie w podejmowaniu wspólnych działań dla poprawy warunków życia. Realizowano ją m.in. przez swobodę przepływu ludzi czy też przez prowadzenie wspólnej polityki w zakresie handlu, rolnictwa, transportu, ochrony środowiska, rynku i prawodawstwa z tym związanego ${ }^{41}$.

Punktem zwrotnym stała się reforma walutowa przeprowadzona 18 czerwca 1948 r. w Niemczech Zachodnich przez okupantów. Wspomniana reforma była ściśle powiązana z reformą gospodarczą - mianowicie musiała istnieć zgodność ideologii systemu politycznego z przyjętym systemem pieniężnym ${ }^{42}$. Od tego momentu rozpoczął się okres prosperity w Niemczech Zachodnich zwanym cudem gospodarczym (Wirtschaftswunder) ${ }^{43}$.

Wpływ przyjętej społecznej gospodarki rynkowej można odnaleźć w katalogu praw socjalnych zawartym w rozdziale drugim ustawy zasadniczej z 23 maja 1949 r. ${ }^{44}$. W ustawie zagwarantowano m.in. równouprawnienie kobiet i mężczyzn w szczególności w odniesieniu do ustalania wysokości płacy (art. 3) oraz otoczenia szczególną opieką instytucji małżeństwa i rodziny (art. 6). W rozdziale czwartym zagwarantowano z kolei szczególne prawa do opieki nad matkami. Ustawo-

\footnotetext{
${ }^{39}$ H. G. Schachtschnabel, Sozailpolitik, Stuttagrt, Berlin, Köln, Mainz 1983, s. 15.

${ }^{40}$ Ibidem, s. 82.

${ }^{41}$ I. Kienzler, Leksykon Unii Europejskiej, Warszawa 2003, s. 81.

${ }^{42}$ T. Kaczmarek, P. Pysz, Ludwik Erhard $i$ społeczna gospodarka..., op. cit., s.71.

${ }^{43}$ J. Krasuski, Historia Niemiec, Warszawa 2004, s. 520.

${ }^{44}$ Grundgesetz für die Bundesrepublik Deutschland vom 23. Mai 1949, BGBl, s. 1.
} 
dawca uregulował ponadto w rozdziale pierwszym kwestię wolności pracy oraz prawa wyboru zawodu (art. 12) ${ }^{45}$.

Poprzez anulowanie zadłużeń III Rzeszy zabezpieczono gospodarkę przed inflacyjnym działaniem odłożonego popytu konsumpcyjnego. Państwo pobudzało dziedziny produkcji i usług, które zaspokajały elementarne potrzeby takie jak: środki spożywcze, odzież czy materiały budowlane. Priorytetem państwa było budownictwo mieszkaniowe. Od 1950 r. działał system ulg i zachęt stymulujących budownictwo indywidualne. Pożyczki na te cele wynosiły $64 \%$ kredytów państwowych. W związku z tym powołano Niemiecki Bank Federalny, sprawujący realną kontrolę nad budżetem. Zgodnie z ordoliberalną konstrukcją manipulowano stopą dyskontową, prowadząc operacje bankowe.

27 lipca 1957 r. Bundestag przyjął ustawę przeciwko ograniczeniom konkurencji, nazwaną wielką kartą społecznej gospodarki rynkowej. Najważniejszy był art. 1 ustawy, który zakładał, że umowy zawierane przez przedsiębiorstwa lub związki przedsiębiorstw uznaje się za nieważne o ile wpływają na produkcję lub stosunki rynkowe w dziedzinie obrotu towarów lub usług przez ograniczenie konkurencji. Ustawa regulowała 3 formy zakłócające konkurencję: kartele, kształtowanie cen oraz przedsiębiorstwa opanowujące rynek. W celu ochrony konkurencji powołano do życia Federalny Urząd Antykartelowy, uprawniony do wydawania zakazu działalności firm lub ich związków, działających sprzecznie z zasadami gospodarki konkurencyjnej.

Najistotniejszym elementem systemu opieki społecznej są ubezpieczenia społeczne, które przybrały w powojennych Niemczech postać składek obowiązkowych i dobrowolnych. Obowiązkowo są płacone przez pracodawców a dobrowolnie przez pracowników. Wprowadzono tym samym, zgodnie z ordoliberalną koncepcją, częściową odpowiedzialność jednostki za swój los uzależniając ideę ubezpieczeń społecznych od wydajności jednostki w grze rynkowej.

Powstanie i rozwój polityki socjalnej w Niemczech Zachodnich był ściśle związany z procesami industrializacji i demokratyzacji społeczeństwa ${ }^{46}$. W zakresie zabezpieczenia socjalnego ustawa z 1952 r.

${ }^{45} \mathrm{Z}$ konstytucyjnie zagwarantowanych praw socjalnych można wyodrębnić następujące dziedziny życia, które są przeniknięte ordoliberalną koncepcja społecznej gospodarki rynkowej. Zalicza się do nich politykę: rodzinną, młodzieżową, bezpieczeństwa społecznego, pomocy socjalnej, mieszkaniową, majątkową, rynku pracy oraz poprawy warunków i stosunków pracy. J. Zersche, Przemiany $w$ polityce socjalnej $w$ Republice Federalnej Niemiec, „Ruch Prawniczy, Ekonomiczny, i Socjologiczny” 1978, nr 4, s. 195.

${ }^{46}$ Ibidem, s. 7. 
wprowadziła 14-tygodniowy płatny urlop macierzyński. Natomiast od 1954 r. są przyznawane zasiłki dla rodzin wielodzietnych. Kolejną ważną reformę przeprowadzono w 1957 r. w zakresie systemu obliczania emerytur i rent ${ }^{47}$. Od tego czasu emerytury i renty sukcesywnie wzrastały, ponieważ co roku następowała ich rewaloryzacja w stosunku do przeciętnego wzrostu płac, dzięki temu udało się uniknąć zgubnych konsekwencji inflacji. Ubezpieczenia na wypadek choroby chronią pracowników i ich rodziny przed wysokimi kosztami leczenia. Podobnie chronią pracowników od wypadków przy pracy oraz zachorowań na choroby zawodowe. Natomiast ubezpieczenia od bezrobocia mają na celu doprowadzić do złagodzenia skutków utraty pracy dla jednostki oraz jego rodziny. Świadczenia te występują w dwóch formach:

- Arbeitslosengeld - czyli zasiłek w wysokości 60\% ostatniej płacy wypłacanego przez 18 miesięcy od dnia utraty pracy;

- Arbeitslosenhilfe, czyli zapomogi dla bezrobotnych w wysokości 50\% ostatniej płacy, a wypłacanej po upływie 18 miesięcy od utraty pracy.

Poza ubezpieczeniami społecznymi funkcjonują także świadczenia społeczne pozaubezpieczeniowe, które obejmują pomoc społeczną, zaopatrzenie państwowe, zasiłki dla dzieci, pomoc mieszkaniową, stypendia dla uczącej się młodzieży etc. Do słabych stron społecznej gospodarki rynkowej w Niemczech Zachodnich należą dwie dziedziny, które nie były w tym wymiarze popierane przez ordoliberałów: polityka antymonopolistyczna i polityka majątkowa.

W aspekcie wewnętrznym słabość polityki antymonopolowej polegała na akceptacji koncentracji struktury przemysłu, pionowych powiązaniach cenowych oraz nieefektywnym funkcjonowaniu Federalnego Urząd Antykartelowego. Natomiast w aspekcie zewnętrznym polityka antymonopolowa polegała na utworzeniu 18 kwietnia $1951 \mathrm{r}$. Europejskiej Wspólnoty Węgla i Stali, której celem było ograniczenie powstawania monopoli w produkcji węgla i stali, porozumień kartelowych oraz niedopuszczenie do ponownego odrodzenia się Niemiec jako potęgi militarnej. W rezultacie jednak nie zapobiegła tworze-

${ }^{47}$ Przed 1957 r. wysokość emerytur i rent ustalano na podstawie nominalnych wysokości składek ubezpieczeniowych wnoszonych w ciągu całego okresu pracy zarobkowej. W konsekwencji emerytury i renty nie były ściśle powiązane z dynamiką płac, co wymagał ciągłego dostosowywani ich do zmieniających się płac i cen. W celu zlikwidowania tych trudności podjęto w 1957 roku reformę o wyrównaniu rent i emerytur według wyżej wspomnianych zasad. Szerzej: J. Piasny, J. Woś, System zabezpieczenia socjalnego ludności..., op. cit., s.8. 
niu się wspomnianych monopoli ${ }^{48}$. Do dalszych wad należy zaliczyć opóźnione rozpoczęcie procesu uwłaszczenia zainicjowane ustawą z 21 maja 1951 r. stanowiącą o parytetowym współzarządzaniu w przemyśle węgla i stali oraz zakładanie stopniowej redukcji budżetu socjalnego państwa w miarę wzrostu zamożności społeczeństwa ${ }^{49}$.

Już w 1952 r. Müller-Armack głosił, iż mówiąc o wprowadzeniu konkurencji nie tyle miał na myśli rekonstrukcję gospodarki rynkowej ile chodziło mu o „styl życia”, ponieważ liberalny model okazał się niewłaściwy ${ }^{50}$. W latach 1957-1962 podjął próbę przewartościowania koncepcji społecznej gospodarki rynkowej. Głównym celem władzy politycznej miał być wzrost ekonomiczny. Jego realizację opierano na powiązaniu metod polityki koniunkturalnej z programem społecznym. Zatem ideał ładu rynkowego byłby oparty na wyrównywaniu szans społecznych dążąc do stworzenia przyjaznego człowiekowi ekosystemu. Realizacja tego planu polegałaby po pierwsze na dostępie do zawodów wysokokwalifikowanych, na które nowoczesna gospodarka zgłaszałaby popyt, poprzez rozwój szkolnictwa zawodowego, wyrównanie szans studiowania; po drugie, na kształtowaniu odpowiedniego środowiska pracy, podwyższeniu standardów bezpieczeństwa i higienie pracy; po trzecie, na usprawnieniu sektora usług publicznych i reorientacji polityki budżetowej; po czwarte na zwiększeniu rangi planowania przestrzennego, w tym świadomego kształtowania układów urbanizacyjnych i ochrony środowiska.

${ }^{48}$ Najjaskrawszym przykładem stworzenia martwej litery prawa w zakresie postanowień antykartelowych była ustawa z 17 maja 1950 roku, którą najlepiej w praktyce ukazuje próba sprzedaży zakładów Kruppa. Wraz z 1952 rokiem nastąpiło złagodzenie kontroli aliantów nad przestrzeganiem tego prawa. 4 marca 1953 r. rozpoczął się proces podzielenia zakładów Kruppa. Własność Zakładów miała być sprzedana, a kwota ze sprzedaży zwrócona właścicielowi Alfredowi Kruppowi von Bohlen und Halbach. Początkowo alianci przekazali dwie spółki przemysłu przetwórczego jego siostrze i siostrzeńcowi. W jego rękach pozostawiono: stocznie okrętowe, fabryki maszyn i przedsiębiorstwa handlowe. Pod pozorem braku nabywców Krupp nie sprzedał swoich zakładów. Uzyskawszy zgodę członków Europejskiej Wspólnoty Węgla i Stali kupił Stahlwerke Bochum, dzięki temu zaczął kontrolować 3\% całej produkcji węgla i stali Wspólnoty; por. J. Krasuski, Historia..., op. cit., s. 536 - 537.

${ }^{49} \mathrm{Na}$ podstawie ustawy z 21 maja 1951w skład rad nadzorczych weszła równa liczba przedstawicieli pracy i kapitału oraz neutralny przewodniczący wybierany przez obie strony.

${ }^{50}$ R. Skarzyński, Państwo i społeczna gospodarka rynkowa. Główne idee polityczne ordoliberalizmu, Poznań 2005, s. 142 i nast. 
Kiedy Müller-Armack tworzył drugą koncepcję społecznej gospodarki rynkowej, Erhard w 1965 roku na zjeździe CDU i CSU ogłosił hasło „uformowanego społeczeństwa”, jako drugiej udoskonalonej fazy społecznej gospodarki rynkowej. W uformowanym społeczeństwie miejsce jednostek w układzie społecznym zostało już zakorzenione w ich świadomości. Dzięki temu interes społeczeństwa znajduje się wyżej aniżeli interes jednostki. W skutek tego nie ma walki między grupami społecznymi o pierwszeństwo w realizacji interesów i potrzeb, a dążące do dominacji ugrupowania polityczne stanowią przejaw pluralizmu, charakteryzujący nowoczesne społeczeństwa, w których jest miejsce dla organizacji pracowników i pracodawców, ruchów ekologicznych i kobiet, związków regionalnych i religijnych. Jednakże po 1963 roku w wyniku zmiany sił politycznych w Niemczech Zachodnich, nie udało się wprowadzić drugiej koncepcji społecznej gospodarki rynkowej.

Podsumowując należy zaznaczyć, że liberalna gospodarka rynkowa nie jest autonomiczna, dlatego też nie może pełnić funkcji regulatora i stabilizatora ładu ${ }^{51}$. Podlega wielu wpływom zewnętrznym, co doprowadza do deregulacji jej mechanizmów, zdeformowania wolnej konkurencji oraz prawa popytu i podaży. Sam rynek nie tworzy zatem żadnych wartości kulturowych, ani nie umiejscawia człowieka w społeczeństwie. Ład społeczny nie może funkcjonować tylko dzięki związkom ekonomicznym. Jeżeli rynkowi zostałaby powierzona funkcja regulatora życia społecznego, to taka sytuacja doprowadziłaby do jego samounicestwienia nie tylko w skutek monopoli, ale także w rezultacie upadku ładu społecznego. Stąd też rozważania na temat społecznej gospodarki rynkowej stanowią impuls do podjęcia dyskusji nad rewizją doktryny neoliberalizmu oraz jej wpływu na kierunek rozwoju przyszłej Europy.

\section{SUMMARY}

After World WAR II the Federal Republic of Germany was forced to decide about its economic system, choosing between liberalism and collectivism. However, neither of the two systems was suitable for German society, so German legal power sought an intermediate solution, a doctrine which would be located halfway on a scale between the

\footnotetext{
${ }^{51}$ R. Skarzyński, Państwo i spoteczna gospodarka rynkowa..., op. cit., s.57 i nast.
} 
two above-mentioned extremes. The resulting solution was the ordoliberal concept of the social market economy, a new economic doctrine implemented by Ludwig Erhard, Economics Minister, later elected Chancellor. The social market economy has since grown in importance, as it was adopted by The European Coal and Steel Community in 1951, and by The European Economic Community in 1957, finally becoming the leading economic doctrine in Europe.

\section{Nota O AUTORZE}

Marta Balcerek [martabalcerek@gazeta.pl] - studentka V roku politologii na Wydziale Nauk Politycznych i Dziennikarstwa UAM w Poznaniu. W kręgu zainteresowań badawczych znajduje się zarówno polski jak i niemiecki samorząd specjalny i samorząd terytorialny, społeczna gospodarka rynkowa oraz kultura polityczna Polski i RFN. Autorka artykułów z zakresu samorządu gospodarczego i społecznej gospodarki rynkowej. 